\title{
2 段配筋された梁主筋の付着割裂強度に関する研究 A STUDY ON BOND SPLITTING STRENGTH OF DOUBLE LAYERED BEAM BARS
}

\author{
田畑＼cjkstart卓*, 西原＼cjkstart寛*, 師 橋 憲 貴**, 桜田智之*** \\ Taku TABATA, Hiroshi NISHIHARA, Noritaka MOROHASHI \\ and Tomoyuki SAKURADA
}

\begin{abstract}
It has been pointed out in recent studies that the bond design for the double layer reinforcement as indicated in the past is not adequate. At the present, however, as enough test data has not been accumulated a rational design method regarding the double layer reinforcement is yet to be determined. A bond test using the simple beam type specimen was executed in which the outer layer reinforcement number, the transverse reinforcement ratio and the bar arrangement of the transverse reinforcement were selected as parameter. As a result, it was found that the influence of the outer layer reinforcement, regarding the bond splitting strength to inner layer reinforcement, is not too large if the main reinforcement bars number of outer layers is more than that of the inner layers. Based on the consideration that the inner layer reinforcement was restrained in the vertical direction by the bond stress of outer layer reinforcement, the previous bond splitting strength equation was revised. The derived equation showed good agreement with the previous experimental results.
\end{abstract}

keywords : double layer reinforcement, bond splitting strength, beam member, transverse reinforcement, inner supplementary tie 2 段配筋, 付着割裂強度, 梁部材, 横補強筋, 中子筋

1.はじめに

鉄筋コンクリート造建物における梁部材の設計では，所要の曲げ 耐力を確保するに足る主筋量が 1 段で配筋しきれない場合，これを 2 段配筋とし対処するのが一般的である。このような 2 段配筋梁の 付着割裂破填の検定は, 従来, 1 段目主筋と 2 段目主筋を独立に扱 えるものと考えて，1 段配筋部材の研究成果をそのまま準用する形 で行われてきた。もつとも，通常は 2 段目に 1 段目より多くの主筋 が配されることはないので，付着の検定は 1 段目主筋のみを対象と して行われることになる。つまり，2 段目主筋の付着割裂破壊は起 こり得ないと考えられていた。しかし，最近，2段配筋に関する研 究が盛んに行われるようになり，これらの評価方法が十分でないこ とが指摘されている。その中でも特に，2 段目主筋の付着割裂強度 の評価に問題があるようである。

大屋戸ら ${ }^{1)}$ が行った実験では，1段目と 2 段目の主筋量が等しい 場合において，2 段目主筋の付着割裂破壊が確認され，2 段目主筋 の付着割裂強度は 1 段目主筋に比べ極めて低いことが示された。ま た, 對比地ら 2)，3) は 1 段目主筋の引張り力を変動因子とする片持 ち梁形式の引抜き実験で，2段目主筋の付着割裂強度が 1 段目主筋 の引張り力の増加に伴って低下することを確認し，1 段目主筋の影 響を考虑した 2 段目主筋の付着割裂強度式を提案している。これら
の研究成果に鑑み, 勒性保証型耐震設計指針 ${ }^{4}$ ( 以下, 勒性保証指 針)でも，新たに2段目主筋の付着設計が取り入れられた。

しかし, 現状では, 実験データは十分に蓄積されているとはいえ ず不明な点も多く残されている。特に既往の実験は，2段目主筋が 付着に対して厳しくなるよう 2 段目主筋量を 1 段目主筋と同等か若 しくはそれ以上に計画している場合が多く, 通常の設計範囲である 1 段目主筋が 2 段目主筋と同量以上となる場合については実験デー タが限られている。また, 中子筋の有無など, 横補強筋の配筋形式 の違いは，1 段配筋部材を対象とした研究 5)6)において，付着割裂 強度を支配する 1 つの大きな要因として捉えられているが，2段配 筋部材に対するその影響については, 付着割裂性状も含めあまり研 究が進んでおらす㭘討の余地がある。

このようなことから，本研究では 1 段目に 2 段目と同量以上の主 筋を有する 2 段配筋梁を想定した単純梁形式の付着割裂実験を行い, 付着割裂強度および付着割裂性状に及ぼす 1 段目主筋本数, 横補強 筋の配筋形式の影響を検討した。また, 既往の付着割裂強度式と本 実験とを比較検証し，文献 ${ }^{2)}$ の式に修正を加える形で付着割裂強 度式を提案した。さらに，付着割裂破壊を考虑したせん断耐力の評 価も試みた。

\footnotetext{
$*$ 安藤建設侏技術研究所

** 日本大学生産工学部建築工学科 助手 $\cdot$ 工修

*** 日本大学生産工学部建築工学科 教授 $\cdot$ 工博
}

ANDO Corporation Research Center

Research Assoc., Dept. of Architecture and Architectural Engineering, College of Industrial Technology, Nihon University, M. Eng.

Prof., Dept. of Architecture and Architectural Engineering, College of Industrial Technology, Nihon University, Dr. Eng. 


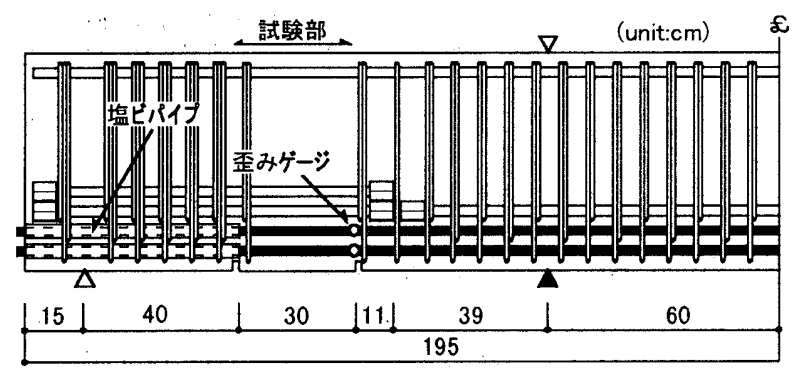

図1試験体形状および配筋例

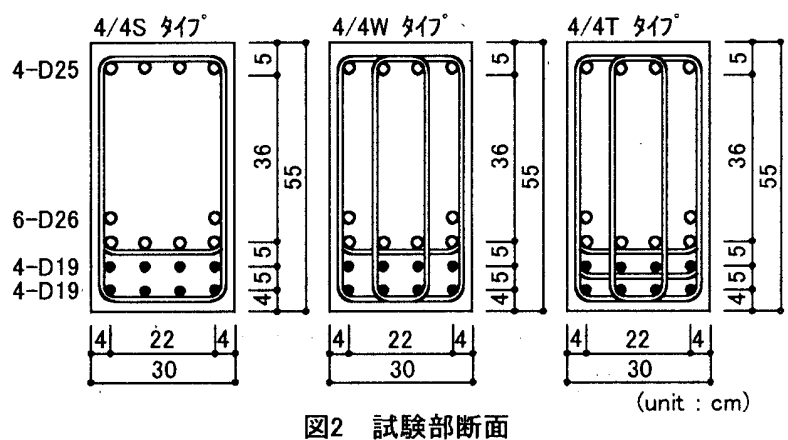

\section{2. 実験概要}

\section{1 試験体}

図1，図2に試験体形状および試験部断面を例示する。試験体は市 之瀬ら フの試験体を参考にした $\mathrm{b} \times \mathrm{D}=30 \times 55 \mathrm{~cm}$ の単純梁で, 左右 両端に個別の試験部を有する。試験鉄筋には D19(竹節)の，横補強 筋には10申の高強度鉄筋を用いた。試駼鉄筋を下端主筋として配し 試験部の長さ，即ち付着測定区間長さは $30 \mathrm{~cm}\left(=15.8 \mathrm{db}, \mathrm{db}_{\mathrm{b}}\right.$ ：主筋 径)とした。試験部は下端より加力点に向かう斜め $45^{\circ}$ のせん断ひ び割れを想定して，加力点から 1 段目主筋の有効せいに相当する位 置 $(=50 \mathrm{~cm})$ の外側に設けた。試験鉄筋の端部は塩ビパイプを被せコ ンクリートとの付着をなくし，支点反力による主筋拘束の影響を排 除した。また, 試験区間の付着応力度が平均的になるように, 試験 部両端の下端に曲げせん断ひび割れを誘発するための切り欠き(幅 $12 \mathrm{~mm}$ ，深さ $25 \mathrm{~mm}$ )を設けた。さらに付着割裂破壞以前の主筋降伏 およびせん盺破壊を避けるため，試験鉄筋の内側に補強用軸方向筋 (D26，齐ジ節 PC 鋼棒)を配した。補強用軸方向筋は加力点から $39 \mathrm{~cm}$ の位置で切断し，端部に定着用のナットを固定した。

表1に試験部一覧を示す。実験は 4/4S，4/4W，4/4T，5/4S，6/4S タイプの 5 種類で構成される全 16 試験部について行った。各々，2 段目主筋は 4-D19 で共通であるが，1 段目主筋は 4/4S，5/4S，6/4S タイプで 4-D19，5-D19，6-D19 と変化させている。既往の研究で は，1 段目主筋量が增すほど 2 段目主筋の付着割裂強度が低下する と指摘されており，この3タイプの試験部でその性状を検討する。 一方，4/4S，4/4W，4/4T タイブは相互に横補強筋の配筋形式を変 化させた試験部である。4/4S タイブは外周補强筋のみとし，4/4W タイプは外周補強筋に中子筋を併用している。4/4T タイプは 4/4W タイプに対してさらに 2 段目主筋に直接掛かる横補強筋(以下，内 側補强筋)を配している。このとき，4/4T タイプでは 2 段目主筋の 付着割裂面に対する横補強筋比（以下， $\mathrm{pw}$ 2)が，1 段目主筋のそれ の 1.5 倍となる。各タイプでは $\mathrm{p}_{\mathrm{w}}=0 \sim 1.89 \%$ の範囲で横補强筋比 を変化させた。なお，横補強筋は試験部両端からそれぞれ $2 \mathrm{~cm}$ 加 力点側にずらした $30 \mathrm{~cm}$ の区間で，所要の横補強筋比となるよう均

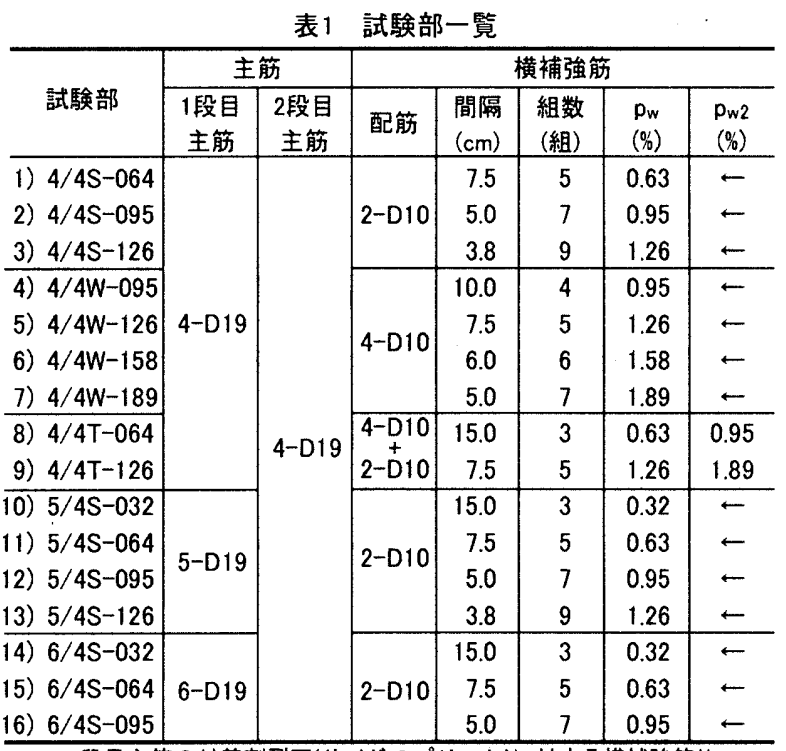

$$
\text { P } \mathrm{P}_{\mathrm{w}} \text { ：1段目主筋の付着割裂面(サイドスプリット)に対する横補強箉比 }
$$
P w2：2段目主筋の付着割裂面(サイドスプリット)に対する横補強筋比

\begin{tabular}{|c|c|c|c|c|c|c|c|c|c|}
\hline 種別 & \multicolumn{2}{|c|}{ 使用䓢所 } & $\begin{array}{c}\text { 降伏強度 } \\
(\mathrm{MPa}) \\
\end{array}$ & \multicolumn{2}{|c|}{$\begin{array}{c}\text { 降伏雪み } \\
(\%)\end{array}$} & \multicolumn{2}{|c|}{$\begin{array}{c}\text { 引張強度 } \\
(\mathrm{MPa})\end{array}$} & \multicolumn{2}{|c|}{$\begin{array}{c}\text { ヤング係数 } \\
(\mathrm{GPa})\end{array}$} \\
\hline D19 & \multicolumn{2}{|c|}{ 主筋 } & 740 & & 0.41 & \multicolumn{2}{|c|}{962} & \multicolumn{2}{|c|}{188} \\
\hline $10 \phi$ & \multicolumn{2}{|c|}{ 横補强筋 } & $836 *$ & & $0.66^{*}$ & & 1178 & & 82 \\
\hline \multicolumn{6}{|c|}{ b) コンクリート } & \multicolumn{4}{|c|}{ *0.2\%オフセット } \\
\hline \multirow{2}{*}{\multicolumn{2}{|c|}{$\begin{array}{c}\text { 圧縮強度 } \\
(\mathrm{MPa})\end{array}$}} & \multirow{2}{*}{$\begin{array}{c}\begin{array}{c}\text { 割裂強度 } \\
(\mathrm{MPa})\end{array} \\
\end{array}$} & \multirow{2}{*}{$\begin{array}{r}\text { スランプ } \\
(\mathrm{cm}) \\
\end{array}$} & \multirow{2}{*}{$\begin{array}{c}\text { W/C } \\
(\%)\end{array}$} & \multirow{2}{*}{ 種別 } & \multicolumn{4}{|c|}{ 単位量 $\left(\mathrm{kg} / \mathrm{m}^{3}\right)$} \\
\hline & & & & & & セメト & 水 & 砂 & 砂利 \\
\hline 26 & & 2.43 & 18.0 & 71.5 & 早強 & 259 & 185 & 849 & 961 \\
\hline
\end{tabular}

等配筋した。表 2 に使用材料の特性を示す。コンクリートは最大粒 径 $13 \mathrm{~mm}$ の粗骨材を用いた $\mathrm{F}_{\mathrm{c}}=27 \mathrm{MPa}$ の早強コンクリートである。 打設は断面上端方向から一体打ちで行った。

\section{2 加力および計測方法}

加力は試験鉄筋を引張り側とする 1 方向繰り返し載荷とした。繰 り返しは，平面保持仮定に基づき算定した補強用軸方向筋の切断位 置における主筋応力度が $100 \mathrm{MPa}$ の倍数となる荷重で各 1 回行った。 1 試験体では横補強筋比の低い側の試験部を先に付着割裂破壊させ， その後, 加力点および支点を移動し他方の試験部を加力した。

測定項目は加力点位置の撓み変位, 主筋および横補強笳の歪みで ある。歪みゲージ(検長 $2 \mathrm{~mm}$ ) は全主筋について図1に示す位置の阔 側面に，横補強筋について断面下端から $165 \mathrm{~mm}$ の高さに貼付した。

\section{3. 実験結果}

\section{1 破壊経過}

図3に最大耐力時のひび割れ状況を例示する。各試験部では，切 り欠き(試験体中央側)功加力点へ向かうせん断ひび割れの進展, 拡幅に伴って, 試験区間の試験鉄筋側部に付着による斜めひび割れ が複数発生し耐力が低下した。全試験部で主筋および横補強筋の降 伏は認められなかった。なお，これ以外に発生するひび割れは，最 大耐力以降においても軽微なままであった。

表3に実験結果一覧を示す。ひび割れ状況からは付着㓶裂破壊が 1 段目主筋，2段目主筋のどちらで生じたのか判別できないが，後 述する 3.2 節の検討より，全ての試験部が 2 段目主筋の付着䟧裂破 


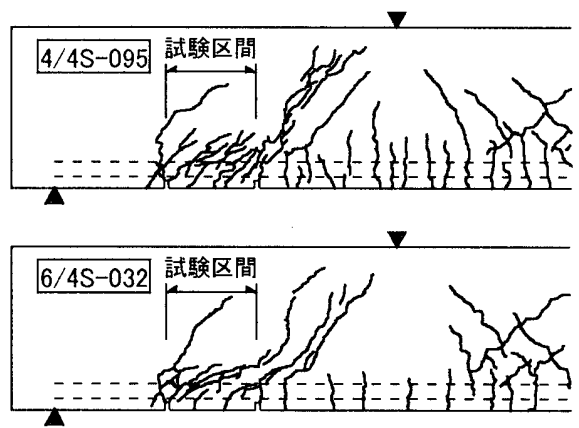

図3 最終破壊状況

壤であると判断された。2 段目主筋では，隅主筋と中間主筋が必ず しも同時に最大付着応力度に達したわけではなかったので, 本論で は，隅主筋と中間主筋とによる平均付着応力度の最大值を付着割裂

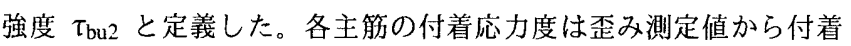
長さ $\mathrm{L}=30 \mathrm{~cm}$ として求めた。

図4に荷重 $\mathrm{P}$ 一撓み $\delta$ 関係の包絡線を要因毎に比較して示す。図 a)の 4/4S-095 と 4/4W-095, 4/4S-126 と 4/4W-126 は各々 $\mathrm{p}_{\mathrm{w}}$ が等し く中子筋の有無のみ異なる試験部であるが，いずれの場合も中子筋 を配した $4 / 4 \mathrm{~W}$ タイプの方が外周補強筋のみの $4 / 4 \mathrm{~S}$ タイプより高 い最大耐力を示しており, 中子筋の効果が認められる。図 b) は横 補強筋間隔を共通にみた場合の, 横補強筋の配筋形式による比較で ある。2 段目主筋高さの横補強筋比 $\mathrm{p}_{\mathrm{w} 2}$ を考えると, 4/4W-126 は 4/4S-064の 2 倍, 4/4T-126 は 4/4S-064の 3 倍であり, 最大耐力は p w2 の增加に伴い上昇する傾向がみられる。図 c)では, 内側補強筋 の効果をさらに検討するため, $\mathrm{p}_{\mathrm{w} 2}$ を共通として 4/4W タイプと 4/4T タイプを比較してみたが, この場合, 4/4W-095 と 4/4T-064, 4/4W-189 と 4/4T-126 のどちらについても最大耐力はほぼ等しくな る結果となった。一方, 図 d), e)は $\mathrm{p}_{\mathrm{w}}=0.32 \%$ と $\mathrm{p}_{\mathrm{w}}=0.95 \%$ の場合 について，1 段目主筋本数による比較をしたものであるが， 1 段目 主筋本数が増すほど最大耐力は高くなる傾向を示している。

表3 実験結果一覧

\begin{tabular}{l|c|c|c|c|c|c|c}
\hline \multirow{2}{*}{ 試験部 } & 最大 & \multicolumn{3}{|c|}{ 付着割裂強度 } & $\tau_{\text {bu1 }}$ & 最終 \\
\cline { 3 - 7 } & $\begin{array}{l}P_{\max } \\
(\mathrm{kN})\end{array}$ & $\begin{array}{c}\tau_{\text {bu20 }} \\
(\mathrm{MPa})\end{array}$ & $\begin{array}{c}\tau_{\text {bu2i }} \\
(\mathrm{MPa})\end{array}$ & $\begin{array}{c}\tau_{\text {bu2 }} \\
(\mathrm{MPa})\end{array}$ & $\begin{array}{c}\tau_{\text {bu1 }} \\
(\mathrm{MPa})\end{array}$ & $\tau_{\text {bu2 }}$ & $\begin{array}{c}\text { 破壊 } \\
\text { 形式 }\end{array}$ \\
\hline 1) $4 / 4 \mathrm{~S}-064$ & 442 & 3.72 & 3.59 & 3.65 & 3.03 & 0.83 & $\mathrm{~B} 2$ \\
2) $4 / 4 \mathrm{~S}-095$ & 564 & 4.18 & 4.53 & 4.35 & 4.14 & 0.88 & $\mathrm{~B} 2$ \\
3) $4 / 4 \mathrm{~S}-126$ & 612 & 4.89 & 5.02 & 4.95 & 4.34 & 0.88 & $\mathrm{~B} 2$ \\
\hline 4) $4 / 4 \mathrm{~W}-095$ & 639 & 3.82 & 4.98 & 4.40 & 5.08 & 1.04 & $\mathrm{~B} 2$ \\
5) $4 / 4 \mathrm{~W}-126$ & 721 & 4.11 & 5.54 & 4.83 & 6.34 & 1.06 & $\mathrm{~B} 2$ \\
6) $4 / 4 \mathrm{~W}-158$ & 750 & 4.38 & 6.12 & 5.25 & 5.86 & 1.04 & $\mathrm{~B} 2$ \\
7) $4 / 4 \mathrm{~W}-189$ & 844 & 4.45 & 6.69 & 5.57 & 7.04 & 1.00 & $\mathrm{~B} 2$ \\
\hline 8) $4 / 4 \mathrm{~T}-064$ & 620 & 4.02 & 4.46 & 4.24 & 4.34 & 1.01 & $\mathrm{~B} 2$ \\
9) $4 / 4 \mathrm{~T}-126$ & 855 & 5.90 & 5.85 & 5.88 & 5.98 & 1.00 & $\mathrm{~B} 2$ \\
\hline 10) 5/4S-032 & 425 & 2.75 & 3.04 & 2.89 & 2.54 & 0.87 & $\mathrm{~B} 2$ \\
11) 5/4S-064 & 520 & 3.29 & 3.61 & 3.45 & 3.26 & 0.89 & $\mathrm{~B} 2$ \\
12) 5/4S-095 & 568 & 3.67 & 3.96 & 3.81 & 3.62 & 0.89 & $\mathrm{~B} 2$ \\
13) 5/4S-126 & 641 & 4.51 & 4.67 & 4.59 & 3.96 & 0.85 & $\mathrm{~B} 2$ \\
\hline 14) 6/4S-032 & 439 & 2.57 & 2.71 & 2.64 & 2.34 & 0.81 & $\mathrm{~B} 2$ \\
15) 6/4S-064 & 525 & 3.33 & 3.50 & 3.41 & 3.05 & 0.84 & $\mathrm{~B} 2$ \\
16) 6/4S-095 & 632 & 3.97 & 4.12 & 4.04 & 3.86 & 0.86 & $\mathrm{~B} 2$ \\
\hline
\end{tabular}

$\tau_{\text {bu2o }}\left(\tau_{\text {bu2i }}\right): 2 \mathbf{E}$ 目隅主筋(中間主筋)の最大付着応力度

$\tau_{\text {bu2 }}: 2$ 段目全主筋の平均による最大付着応力度

$\tau_{\text {bu1 }}$ : 最大耐力時における1段目全主筋の平均付着応力度

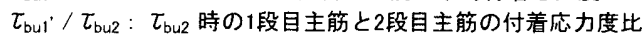

最終破填形式 : B2 $\rightarrow$ 2段目主筋の付着割裂破壊
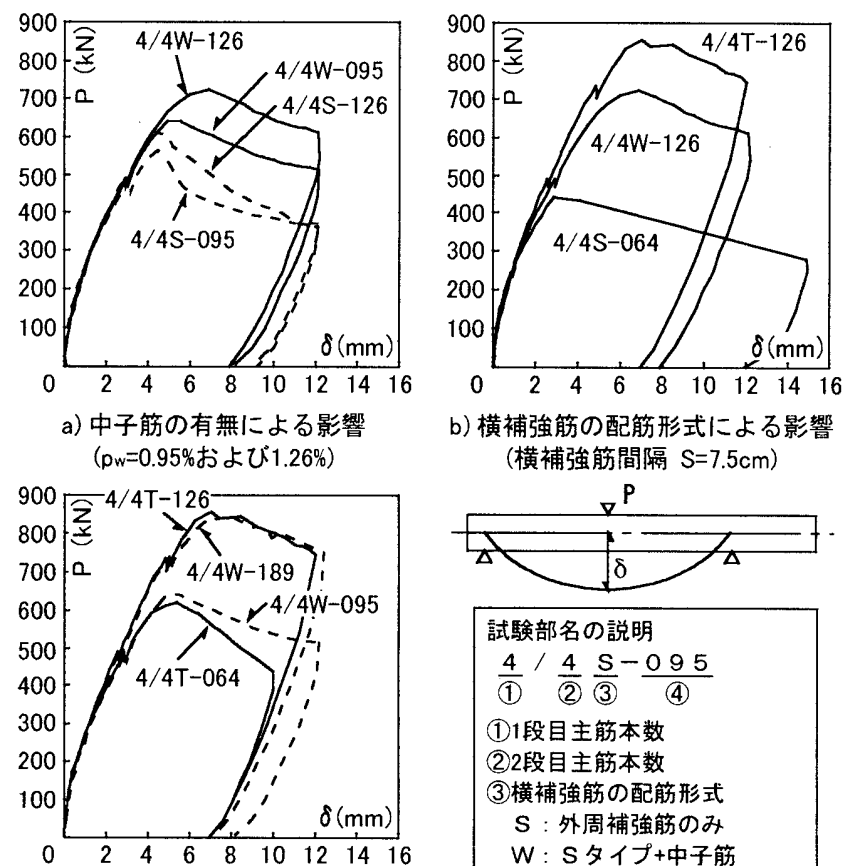

c) 内側補強筋の有無による影響 ( $\mathrm{p}_{\mathrm{w} 2}=0.95 \%$ よぴ $\left.1.89 \%\right)$

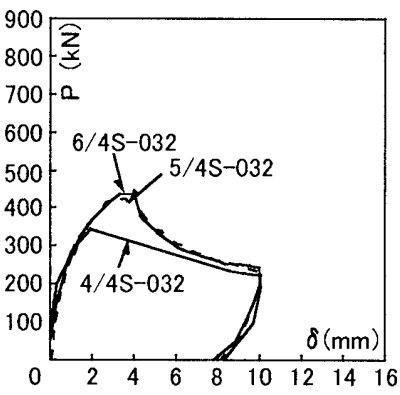

d) 1 段目主筋本数による影響 $\left(\mathrm{p}_{\mathrm{w}}=0.32 \%\right)$

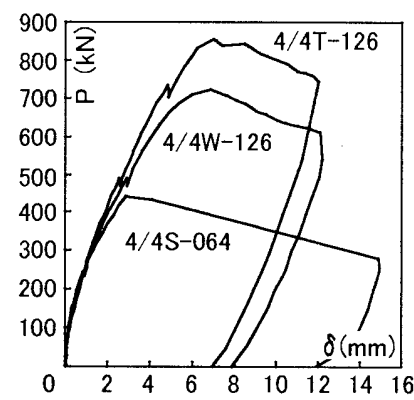

b) 横補強筋の配筋形式による影響 (横補強筋間隔 $\mathrm{S}=7.5 \mathrm{~cm}$ )

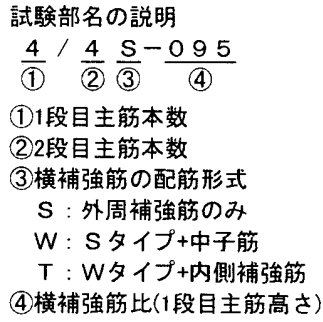

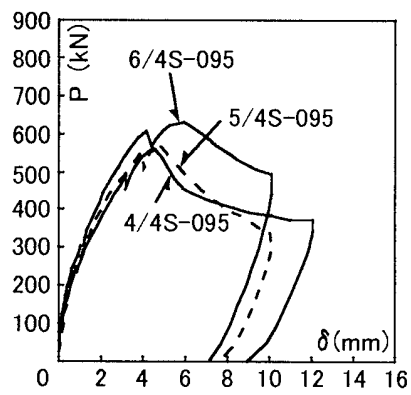

e) 1段目主筋本数による影響 $\left(p_{w}=0.95 \%\right)$

図4 荷重P一撓み $\delta$ 関係

\section{2 各鉄筋の付着応力度と荷重の関係}

図5に 1 段目および 2 段目の各主筋の付着応力度 $\tau_{\mathrm{b} 1}, \tau_{\mathrm{b} 2}$ と荷重 P の関係を示す。ここでは横補強筋の配筋形式が異なる 4/4S-126, 4/4W-126，4/4T-126を取り上げた。

各試験部に共通して，2 段目主筋の付着応力度 $\tau_{\mathrm{b} 2}$ は最大耐力時 もしくはそれ以前に低下し，1 段目主筋の付着応力度 $\tau_{\mathrm{b} 1}$ は最大耐 力以降で横這いまたは上昇する傾向がみられる。1 段目主觔は最大 耐力時において本来の付着割裂強度に達しておらず，2段目主筋の 付着劣化により応力の再分配が為されたため, 最大耐力の後も付着 応力度が上昇したもの考えられる。この傾向は図示しなかった他の 試験部でも確認されており, 従って, 本実験では全ての試験部が 2 段目主筋の付着割裂破壊であると判断した。

横補強筋の配筋形式による影響を検討する。外周補強筋のみの 4/4S-126 では，2段目の隅主筋(3)と中間主筋(4)が最大耐力と同時に 急激に付着低下している。中子筋を配した 4/4W-126 では，隅主筋 (3)の付着低下以降も荷重が上昇し続け，中間主筋(4)の付着低下とと もに最大耐力に至っている。前述したとおり，同一 $\mathrm{p}_{w}$ の場合には 中子筋の有るもの (4/4W-126)の方が無いもの (4/4S-126)に比べ高い 最大酎力を示すが，雨試験部は 2 段目主筋の付着割裂強度 $\tau_{\text {bu2 }}$ に 関して明確な差はなく, 最大耐力の違いは 1 段目主筋の付着応力度 

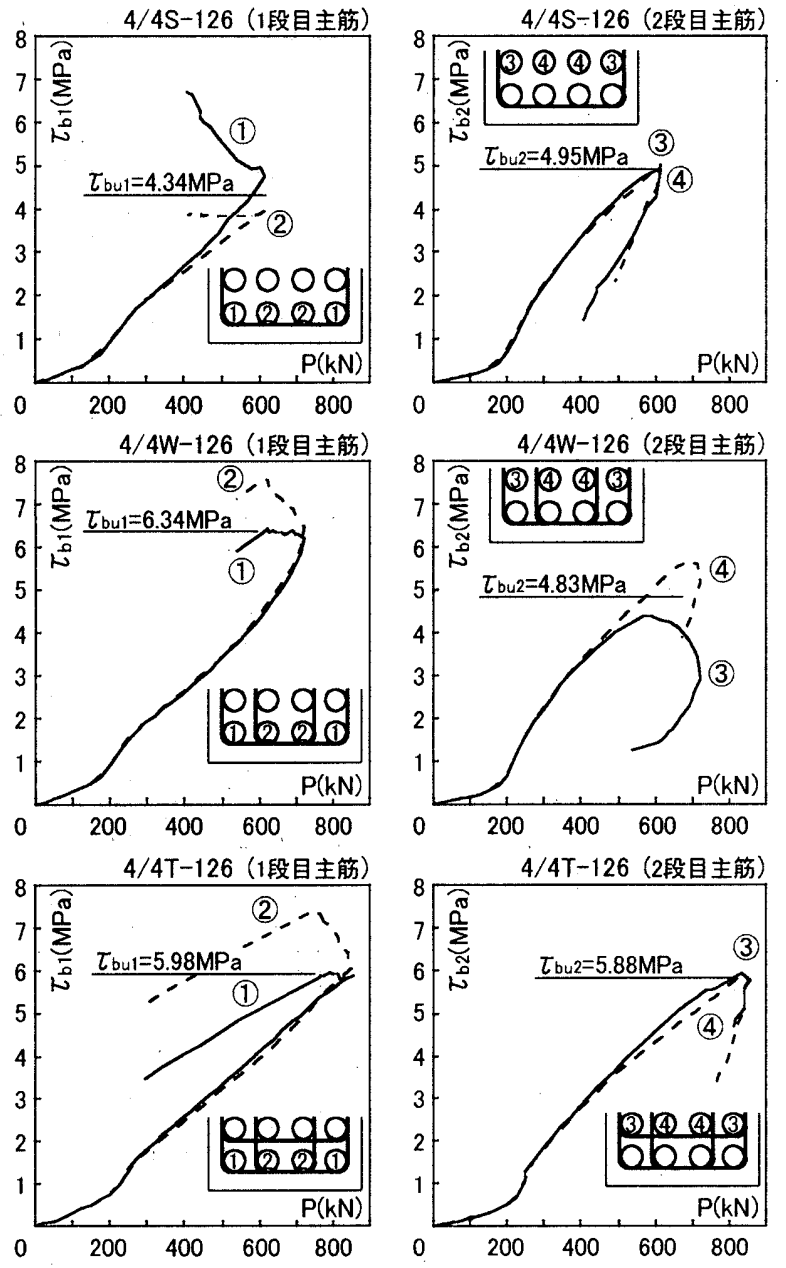

図5 付着応力度 $\tau_{b 1}, \tau_{b 2}$ 一荷重P 関係

の違いによっていることがわかる。4/4T-126 は 4/4W-126に内側補 強筋を追加した試験部である。同試験部では 4/4W-126 でみられた 2 段目隅主筋(3)の付着劣化性状が改善されている。その結果， 2 段 目主筋の付着割裂強度 $\tau_{\text {bu2 } 2}$ は $4 / 4 \mathrm{~W}-126$ の 1.22 倍に達した。

\section{3 横補強筋応力と荷重の関係}

図6は 4/4W タイプと 4/4T タイプについて, 荷重 $\mathrm{P}$ 一横補強筋応 力度 $\sigma_{\mathrm{w}}$ 関係を例示したものである。試験部には幾分のせん断ひび 割れを生じるものの, 最大耐力まで進展・拡幅することなく軽微な ままであったことから， $\sigma_{\mathrm{w}}$ はそのほとんどが付着割裂ひび割れに 対する拘束力として生じたものと考えられる。個々の試験部におい て, 外周補強筋, 中子筋および内側補強筋の履歷はほほ一致してお り，横補強筋の種別に関する負担応力の違いはみられない。また， 内側補強筋を配した 4/4T-064 と 4/4T-126の， $\sigma_{\mathrm{w}}$ が増加し始めてか らの傾きは，それぞれ 2 段目の横補強筋比 $\mathrm{p}_{\mathrm{w} 2}$ が共通の 4/4W-095, 4/4W-189 と概ね等しい。この傾きが横補強筋量に依存することを 考虑すれば，外周補強筋，中子筋および内側補強筋はともに，2 段 目主筋の付着応力に対して同等の拘束力を有していると判断できる。

図7に2 段目主筋の付着割裂強度時の横補強筋応力度 $\sigma_{\mathrm{wu}}$ を示す。 $\sigma_{\text {wu }}$ は $211 \sim 324 \mathrm{MPa}$ の範囲に分布しており, 降伏応力 $(=836 \mathrm{MPa})$ に比してかなり小さい。 $\sigma_{\mathrm{wu}}$ は 1 段目主筋本数の増加とともに大き くなっているようにも見受けられるが，その影響は小さく本実験に おいて両者の関係は明確ではない。
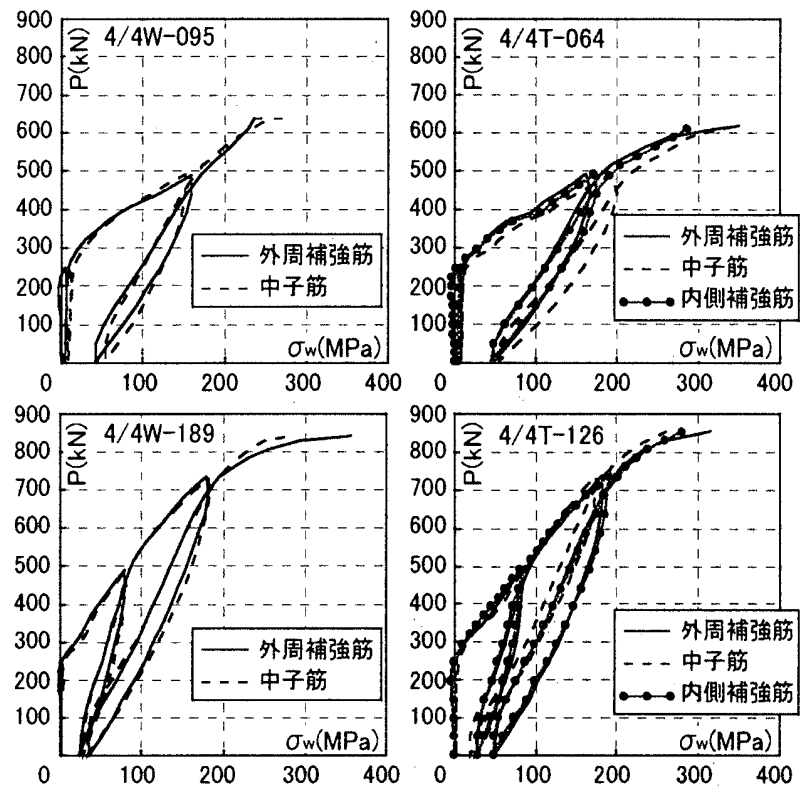

図6 荷重P-横補強筋応力度 $\sigma_{\mathrm{w}}$ 関係

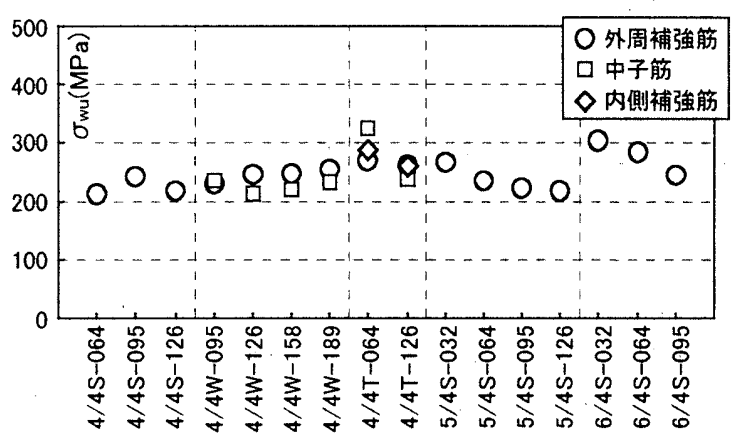

図7 2段目主筋付着割裂破壊時の横補強筋応力度 $\sigma_{w u}$

\section{2段目主筋の付着割裂強度}

4.1 1段目主筋と2段目主筋の付着応力度比

2 段目主筋の付着割裂強度を検討するにあたり，先ず，1段目主 筋の付着応力がどの程度であったか把握しておく必要がある。図8 は2段目主筋が付着割裂強度に達したときの1段目主筋の付着応力 度 $\tau_{\mathrm{bu1}}$ 'と, 2 段目主筋の付着割裂強度 $\tau_{\mathrm{bu} 2}$ との比 $\tau_{\mathrm{bu} 1}$ / $\tau_{\mathrm{bu} 2}$ を示 したものである。図中の一点鎖線は, 補強用軸方向筋の切断位置で 平面保持を仮定した場合の計算值である。付着応力度比は全試験部 で計算值を下回っている(これは補強用軸方向筋の切哳位置から歪 み測定位置までの間で，2段目主筋にほとんど歪み勾配を生じなか つたためである)。また，付着応力度比に 1 段目主筋本数の影響は

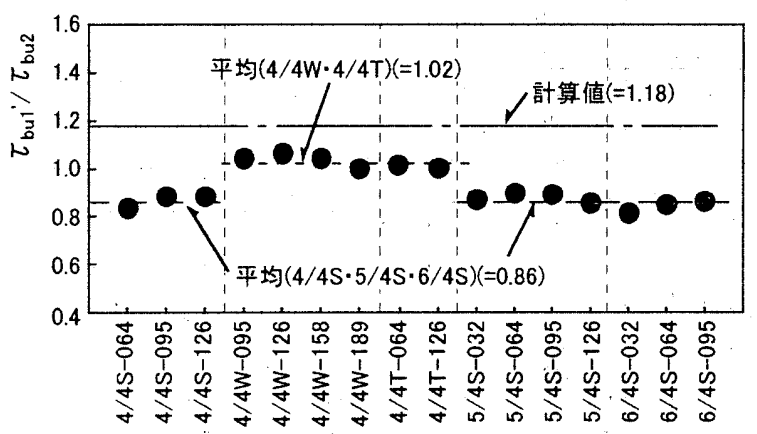

図8 付着割裂破壊時の付着応力度比 $\tau_{\mathrm{bu}} \mathrm{i} / \tau_{\mathrm{bu} 2}$ 

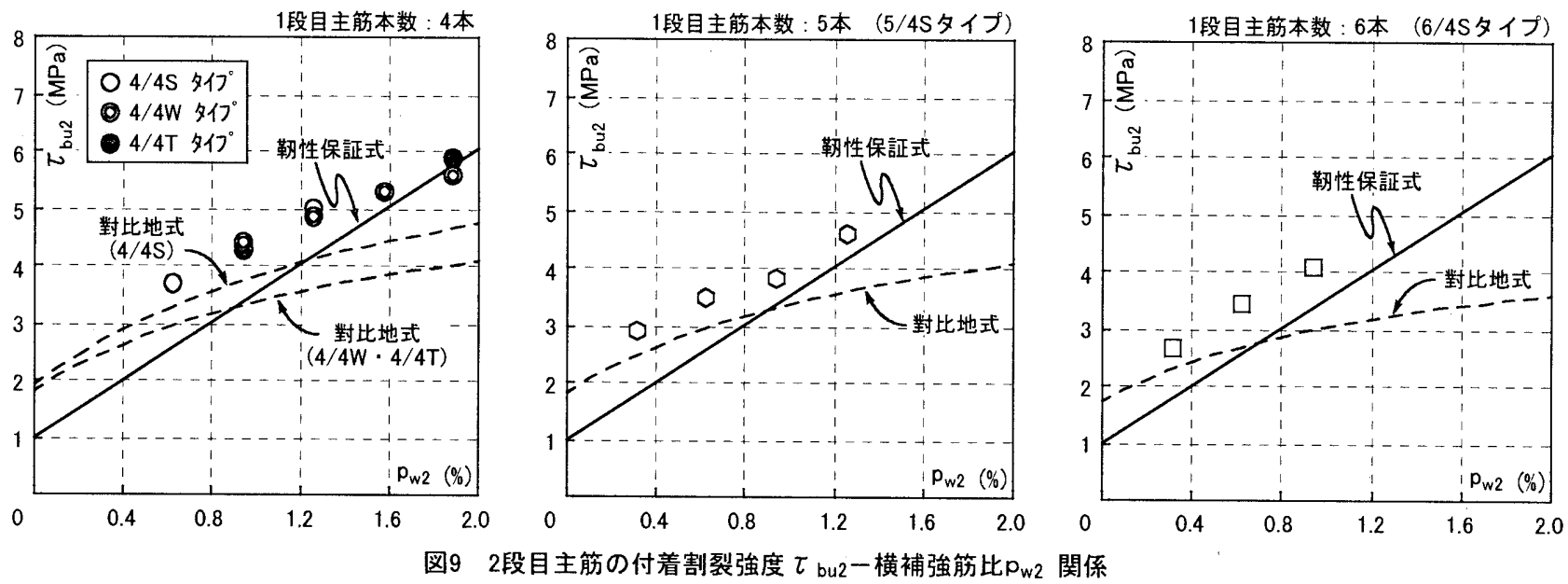

みられず，外周補強筋のみの試験部で平均 0.86 , これ以外の中子筋 や内側補強筋を配した試験部で平均 1.02 となっている。

\subsection{2段目主筋の付着割裂強度と横補強筋比の関係}

図9に 2 段目主筋の付着割裂強度 $\tau_{\mathrm{bu} 2}$ と横補強筋比 $\mathrm{p}_{\mathrm{w} 2}$ の関係を 1 段目主筋本数別に示す。 $\mathrm{p}_{\mathrm{w} 2}$ を用いたのは前節までの考察に基づ き4/4T タイプを他と同一レベルで比較するためである。付着割裂 強度は各タイプで $\mathrm{p}_{\mathrm{w} 2}$ とともに上昇している。 $4 / 4 \mathrm{~S}$ と $4 / 4 \mathrm{~W}$ タイプ, 4/4W と 4/4T タイプではそれぞれ, 同じ $\mathrm{p}_{\mathrm{w} 2}$ を有する試験部が 2 組 あるが，どちらの場合も付着割裂強度はほほ等しい。従って， $\tau_{\text {bu2 }}$ に対して横補強筋の配筋形式は影響しないと考えて良いと思われる。 また，4/4S，5/4S，6/4S タイプの比較では， 1 段目主筋本数による 影響はそれほど明確に現れていないことがわかる。

同図には 2 段目主筋の付着割裂強度式である, 對比地らの提案式 ${ }^{2)}$ (以下, 對比地式) と, 勒性保証指針の評価式 ${ }^{4)}$ (以下, 勒性保証 式)による計算值も併せて示した。両式の詳細を表4に示す。なお， 對比地式における 1 段目 $\cdot 2$ 段目主筋の引張り力比 $\gamma$ は, 前節の付 着応力度比の平均值を用い次式で与えた。

$$
\gamma=\mathrm{T}_{1} / \mathrm{T}_{2}=\left(\tau_{\text {bu1 }}{ }^{\prime} / \tau_{\text {bu2 } 2}\right) \cdot\left(\Sigma \phi_{1} / \Sigma \phi_{2}\right)
$$

$\Sigma \phi_{1} ， \Sigma \phi_{2}:$ それぞれ 1 段目主筋，2段目主筋の周長合計

對比地式は $\mathrm{pw} 2$ の低い範囲で良く適合するものの, $\mathrm{p}_{\mathrm{w} 2}$ が增すに 従って適合性が低下する傾向にある。特に引張り力比の比較的大き

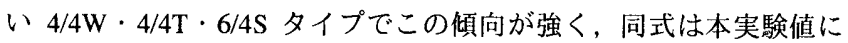
対して引張り力比による影響(1 段目主筋の付着応力による $\tau_{\text {bu2 }}$ の 低下)を過敏に評価しすぎるようである。勒性保証式は本実験の範 囲で 1 段目主筋本数に関わらず一定の付着割裂強度を与えることに なる(表4中， $\alpha_{2}=0.6$ )。実験值との対応は比較的良好であるが, 詳 細にみれば， $\mathrm{p}_{\mathrm{w} 2}$ の小さい範囲で過小評価となる傾向がある。

\section{3 既往の付着割裂強度式の修正}

對比地式および勒性保証式では，1 段目主筋の付着応力が 2 段目 主筋の割裂面に作用することに起因し，2段目主筋の付着割裂強度 は低下すると考えている。その構成は, 基本となる付着割裂強度に 対し，1 段目主筋の影響を表す低減係数を乗じることによっている。 即ち,

$\tau_{\text {bu2 }}=\mathrm{k} \cdot{ }_{\mathrm{o}} \tau_{\mathrm{u}}$

ここで, $\tau_{\mathrm{bu} 2}: 2$ 段目主筋の付着割裂強度, ${ }_{\mathrm{o}} \tau_{\mathrm{u}}$ : 基本付着割裂強

\section{表4２段目主筋を対象とする既往の付着割裂強度式}

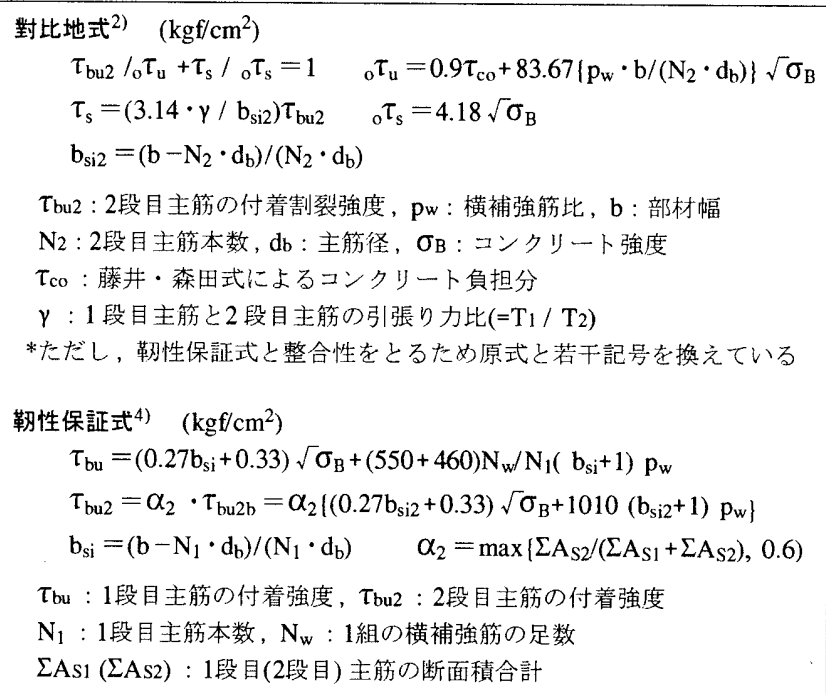

度 (勒性保証式では $\tau_{\text {bu2b }}$ がこれにあたる), $\mathrm{k}$ ：低減係数である。 本実験の範囲で，両式が与える基本付着割裂強度はそれほど大きく 異なっておらず，本実験值との適合差については，低減係数が大き く関与していると判断される。

図10に両式の低減係数を 1 段目· 2 段目主筋の断面積比 $\Sigma$ AS1/LAS2 との関係で示す。ただし，對比地式では断面積比を直接的に扱って いないため，1段目と 2 段目の主筋径が同一で且つ付着応力度比が 1.0 であると仮定して, 引張り力比を断面積比に読み替え評価した。 勒性保証式は設計式としての簡便さから，断面積比のみに依存する 形で低減係数を与えるが，對比地式では更に基本付着割裂強度 ${ }_{0} \tau_{\mathrm{u}}$ の違いも低減係数に影響する。これは。 $\tau_{\mathrm{u}}$ の高いものほど付着割裂 破壞時の 1 段目主筋応力が高く，2段目主筋の付着割裂強度が低下 し易いことを表している。なお，勒性保証式は通常設計される $\Sigma \mathrm{A}_{S 1} / \Sigma \mathrm{A}_{S 2} \geqq 1$ の範囲に対して低減係数 $\alpha_{2}$ を一律 0.6 で与えるが, 実験資料の不足から，その妥当性は今後の課題としている。對比地 式が多くの実験結果に基づいているにも関わらず，本実験との適合 性が思わしくないのは, 主に引張り力比の比較的小さい範囲を対象 としているため, 本実験程度の引張り力比まで追従しきれていない ことが考えられる。そこで, 以降では對比地式の低減係数について 修正を加えることとした。以下に對比地式の概要を示す。

$$
\tau_{\text {bu2 }}=\left(1-\tau_{\mathrm{s}} /{ }_{\mathrm{o}} \tau_{\mathrm{s}}\right) \cdot{ }_{\mathrm{o}} \tau_{\mathrm{u}}
$$




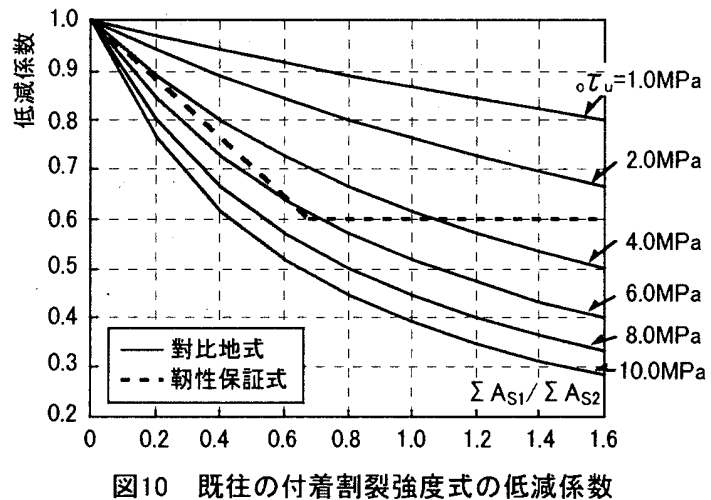

${ }_{\mathrm{o}} \tau_{\mathrm{s}}=4.18 \cdot 0.313 \sqrt{\sigma_{\mathrm{B}}} \quad[\mathrm{MPa}]$

式中， $\tau_{\mathrm{s}}$ は 1 段目主筋の付着応力による 2 段目主筋位置の割裂 面に作用するせん断応力度を，。视 はその限界許容值(原文中では $\tau_{\mathrm{bu} 2}=0$ となるときの $\tau_{\mathrm{s}}$ )を表す。式(3)は見方を変えれば， ${ }_{\mathrm{o}} \tau_{\mathrm{s}}$ をせ ん断強度とするせん断余裕率を低減係数とした式であるといえる。

今, 部材中にトラス機構が形成され，横補強筋応力は 1 段目主筋 と 2 段目主筋の付着応力の和に応じて生じると仮定する。この場合， 2 段目主筋の割裂面には 1 段目主筋の付着応力による鉛直方向の拘 束応力が生じるため，。视は 1 段目主筋量を増すほどに上昇すると 考えられる。このとき，1 段目主筋の付着応力によって 2 段目主筋 の割裂面に作用する鉛直方向の拘束応力度 $\sigma_{\mathrm{v}}$ は, 式(5)のように 表すことができる。

$$
\begin{aligned}
\sigma_{\mathrm{v}} & =\tau_{\text {bu1 }} \cdot \Sigma \phi_{1} \cdot \cot \theta /\left(\mathrm{b}-\mathrm{N}_{2} \cdot \mathrm{d}_{\mathrm{b}}\right) \\
& =\tau_{\text {bu } 2} \cdot \pi \cdot\left(\mathrm{T}_{1} / \mathrm{T}_{2}\right) \cdot \cot \theta / \mathrm{b}_{\mathrm{si} 2}
\end{aligned}
$$

ここで， $\tau_{\text {bu1 }}: 2$ 段目主筋の付着割裂強度時における 1 段目主筋 の付着応力度, $\Sigma \phi_{1}: 1$ 段目主筋の主筋周長の合計， $\theta$ : トラス角度， $\mathrm{b}$ : 部材幅, $\mathrm{N}_{2}: 2$ 段目主筋本数, $\mathrm{d}_{\mathrm{b}}$ : 主筋径である。式(5)に基づ き式(4)を下式のように修正する。

$$
{ }_{o} \tau_{s^{\prime}}=\alpha \sqrt{\sigma_{\mathrm{B}}}+\beta \cdot \tau_{\mathrm{bu} 2} \cdot \pi \cdot\left(\mathrm{T}_{1} / \mathrm{T}_{2}\right) / \mathrm{b}_{\mathrm{si} 2}
$$

また, 本実験および文献 $\left.{ }^{2)} 3\right)$ の結果に対して最も相関係数を高く 与えるよう未知数 $\alpha, \beta$ を求めた結果 $\alpha=1.0, \beta=0.84$ を得た(SI 単

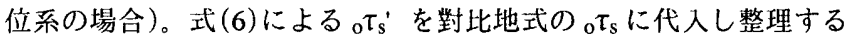
と, 式(7)が得られる。

$\left\{\gamma \cdot \pi /\left(\mathrm{b}_{\mathrm{si} 2} \cdot 0.84 \sqrt{\sigma_{\mathrm{B}}}\right\} \tau_{\mathrm{bu} 2}{ }^{2}+\tau_{\mathrm{bu} 2}-{ }_{\mathrm{o}} \tau_{\mathrm{u}}=0 \quad[\mathrm{MPa}]\right.$

図11は修正式(7)における低減係数と盺面積比 $\Sigma$ AS1/ $/$ AS2 の関係 を，図10の對比地式と同じ仮定条件で示したものである。図10に示 す對比地式の場合と比ベ，断面積比の比較的大きい範囲で，。艄 増加に伴う低減係数の減少が緩やかになっていることがわかる。

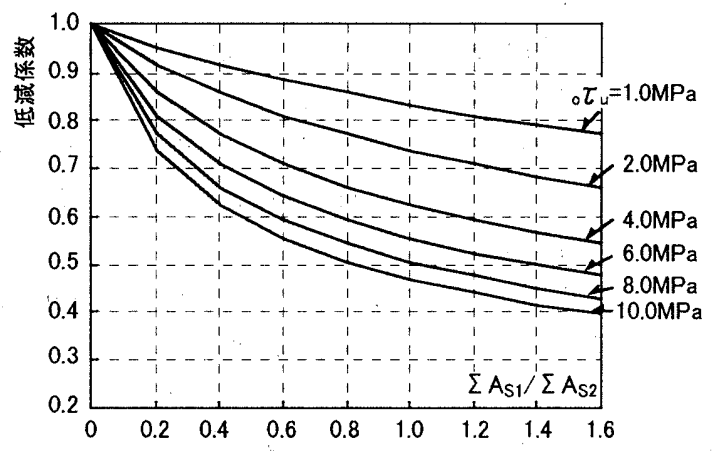

図11 式(7)における低減係数

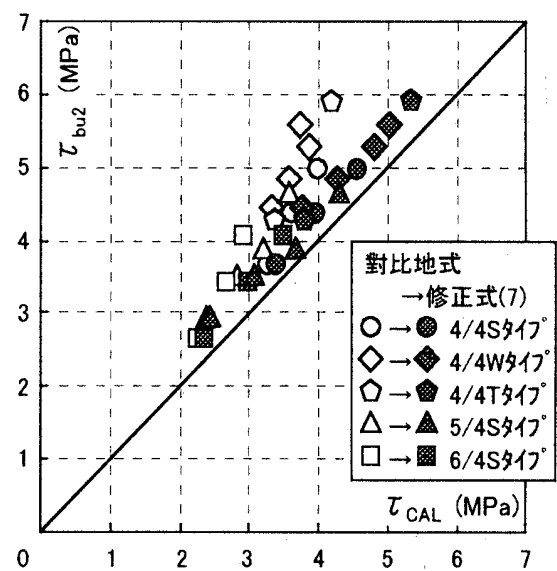

図12 本実験値と對比地式および修正式(7)による計算値の対㡱

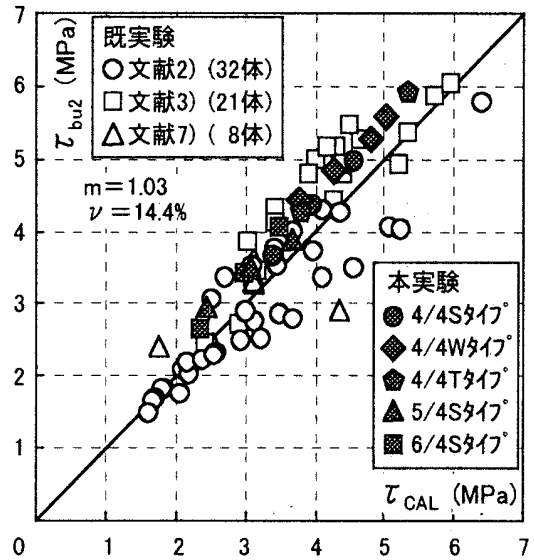

図13 既往の実験結果と修正式(7)による計算值の対応

\section{4 修正式の検証}

図12に本実験値と計算値の関係を，對比地式による場合と修正式 （7）による場合で比較して示す。なお， $\gamma$ は各試験部で個別に得ら れた付着応力度比の実験值に基づき式(1)で与えた。對比地式では $\mathrm{p}_{\mathrm{w}}$ が高くなるに従い実験值と計算值の差が大きくなり安全側に傾 くが, 修正式ではこの傾向が改善され適合性が向上している。

図13は本実験に既往の 2 段配筋梁の付着実験結果 2)、3)、7)を加 え, 修正式による計算值との対応を示したものである。既往の実験 結果は，主筋降伏以前に 2 段目主筋が付着割裂破壊した，または付 着割裂破壊したと推測される61 体である(文献 ${ }^{7}$ では付着割裂破 壊した鉄筋が明示されていないが，1段目と 2 段目主筋量が等しい ことから 2 段目主筋の付着割裂破壊と判断した)。これらの加力形 式はいずれも片持ち梁形式の引抜試験によっており，実験の範囲は $\gamma=0 \sim 1.18, \mathrm{~b}_{\mathrm{si} 2}=1.90 \sim 2.58, \mathrm{p}_{\mathrm{w}}=0 \sim 1.25 \%, \sigma_{\mathrm{B}}=35.6 \sim 48.5 \mathrm{MPa} \tau$ ある。修正式は実験值を計算值で除した比に関して平均 $\mathrm{m}=1.03$, 変動係数 $v=14.4 \%$ あ゙り，実験值と良好な対応を示している。

\section{5 修正式の簡略化}

修正式(7)は 2 段目主筋の付着割裂強度について 2 次方程式を解 く形となるため, 設計式として用いるにはかなり計算が煩雑である。 修正式の妥当性については今後, 更なる実験データの蓄積と検証が 必要と思われるが,ここでは, 修正式により付着割裂強度の推定が 可能であると仮定し，修正式の簡略化を試みた。いま，式(7)より T bu2 を導出する式は式(7')で表される。 


$$
\tau_{\text {bu2 }}=\left(-1+\sqrt{1+2 \omega \cdot{ }_{o} \tau_{u}}\right) / \omega
$$

$$
\text { ただし, } \omega=2 \pi \gamma /\left(\mathrm{b}_{\mathrm{si} 2} \cdot 0.84 \sqrt{\sigma_{\mathrm{B}}}\right)
$$

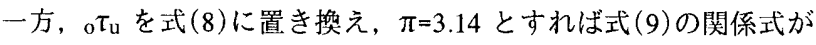
得られる。

$$
\begin{aligned}
& { }_{o} \tau_{\mathrm{u}} \fallingdotseq 0.313\left(0.4+80 \mathrm{p}_{\mathrm{w} 2}\right)\left(\mathrm{b}_{\mathrm{si} 2}+1\right) \sqrt{\sigma_{\mathrm{B}}} \\
& 2 \omega \cdot{ }_{{ }_{o}} \tau_{\mathrm{u}}=1.87\left(1+200 \mathrm{p}_{\mathrm{w} 2}\right)\left\{\left(\mathrm{b}_{\mathrm{si} 2}+1\right) / \mathrm{b}_{\mathrm{si} 2}\right\}
\end{aligned}
$$

式(7')のルート内の 1 を無視する形で式(9)をルートで括り，各 因子の影響を図14および図15に示す回帰直線で評価する。それを整 理することによって簡略式(10)が導かれる。

$$
\begin{aligned}
& \tau_{\text {bu2 }}=\mathrm{k}\left\{0.18 \sqrt{\gamma} \cdot\left(60.5 \mathrm{p}_{\mathrm{w} 2}+1.08\right)\left(1.33-0.052 \mathrm{~b}_{\mathrm{si} 2}\right)-0.09\right\} \\
& \text { ただし, } \mathrm{k}=\mathrm{b}_{\mathrm{si} 2} \cdot \sqrt{\sigma_{\mathrm{B}}} / \gamma
\end{aligned}
$$

[MPa]

図16は 2 段配筋梁の一般に設計されるであろう $\sigma_{\mathrm{B}}=24 \sim 60 \mathrm{MPa}$, bsi2=1.5 5.0, $\gamma=1.0 \sim 3.0$ の範囲について, 修正式(7)と簡略式 (10)の対応を示したものである。図中には参考として勒性保証式に よる計算值も併せて示した。引張り力比 $\gamma$ の条件にもよるが, 勒性 保証式は簡略式と同程度か若しくはそれより小さめの評価を与える 傾向にあることがわかる。

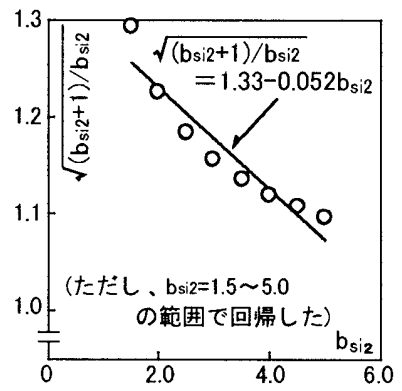

図14 bsi2に関わる簡略化
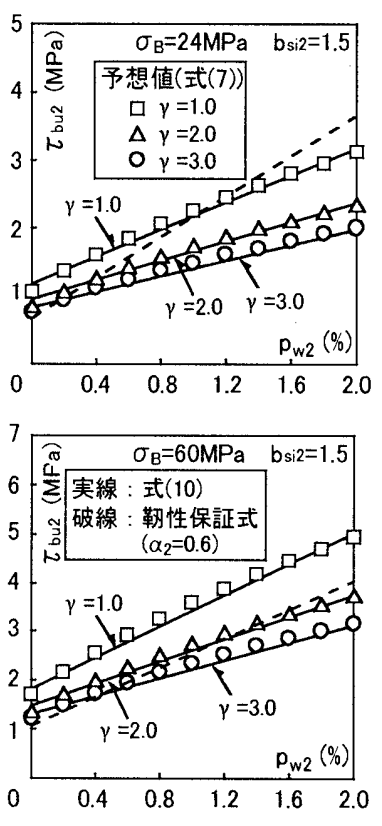

図16 修正式(7)と簡略式(10)の対応

\subsection{2段配筋部材の付着割裂耐力の評価}

本節では, 以下の付着割裂耐力式を考え, 既往の 2 段配筋部材を 対象としたせん断実験結果との比較検証を行った。

$$
\begin{aligned}
& \mathrm{V}_{\mathrm{bu}}=\mathrm{V}_{\mathrm{bt}}+\mathrm{V}_{\mathrm{ba}} \\
& \mathrm{V}_{\mathrm{bt}}=\tau_{\mathrm{bu}} \cdot\left(\Sigma \phi_{1} \cdot \mathrm{je}_{\mathrm{e}}+\Sigma \phi_{2} \cdot \mathrm{je}_{\mathrm{e} 2}\right)
\end{aligned}
$$

$$
\begin{aligned}
& \mathrm{V}_{\mathrm{ba}}=\left\{v \cdot \sigma_{\mathrm{B}}-2.5 \tau_{\mathrm{bu}} \cdot\left(\Sigma \phi_{1}+\Sigma \phi_{2}\right) /\left(\lambda \cdot \mathrm{b}_{\mathrm{e}}\right)\right\}(\mathrm{bD} / 2) \tan \theta \\
& \mathrm{j}_{\mathrm{e} 2}=\mathrm{je}_{\mathrm{e}}-2 \mathrm{~S}_{\mathrm{s}} \\
& \tau_{\mathrm{bu}}=\min \left(\alpha_{\mathrm{t}} \cdot \tau_{\mathrm{bu} 1}, \alpha_{\mathrm{t}} \cdot \tau_{\mathrm{bu} 2}\right) \\
& \alpha_{\mathrm{t}}=0.75+\sigma_{\mathrm{B}} / 4000
\end{aligned}
$$$$
\tau_{\text {bul }}=\left\{0.4 b_{\mathrm{si}}+0.5+19(1+\mathrm{n} / \mathrm{N}) \cdot \mathrm{p}_{\mathrm{w}}\left(\mathrm{b}_{\mathrm{si}}+1\right)\right\} \cdot 0.313 \sqrt{\sigma_{\mathrm{B}}}
$$

ここで， $S_{\mathrm{s}}: 1$ 段目主筋と 2 段目主筋の芯々間距離, $\mathrm{D}$ : 部材せ い, $\mathrm{je}$ : トラス機構に関与する断面の有効せい(文献 ${ }^{4)}$ 参照)

式(11)〜 (16) は勒性保証指針を基としているが，トラス機構によ るせん断酎力を表す式(12)において，2 段目主筋の有効せいを別途 与えること, また, 付着割裂強度は 1 段目と 2 段目主筋の小さい方 を各段に共通に与えることが異なっている。後者については設計の 便を考慮して 1 段目と 2 段目主筋の付着応力度比を 1.0 と仮定した ものであり，どちらか一方の主筋が付着割裂強度に達した時点で付 着割裂耐力が決定するとの考えによる。2 段目主筋の付着割裂強度 は $\gamma=\Sigma \phi_{1} / \Sigma \phi_{2}$ として前節の式(10)により算定する。1 段目主筋の付 着割裂強度は, 文献 ${ }^{8)}$ において, 藤井・森田式 ${ }^{6)}$ による計算值を上 回ることが確認されており, また, 本実験でも最大耐力時の 1 段目 主筋付着応力度 (表3参照)について, 藤井・森田式の $0.79 \sim 1.27$ 倍, 勒性保証式の $0.73 \sim 1.31$ 倍であった。つまり， 1 段配筋の場合より 高くなるであろうと予想されるが, いまのところ, これを適切に評 価し得る式が確立されていないため, ここでは藤井・森田式を中子

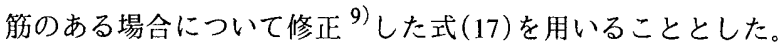

図17に既往の 2 段配筋梁のせん断実験結果 ${ }^{1), 8), 10) ~ 16)}$ と式(10) ～(17)による計算值の関係を示す。縦軸は実験最大耐力 $V_{\exp }$ を, 横軸は式(10) （17）による付着割裂耐力と勒性指針によるせん断耐 力の小さい方の耐力 $\mathrm{V}_{\min }$ を，それぞれ曲げ終局耐力 $\mathrm{V}_{\mathrm{mu}}$ で除して 示してある。曲げ終局耐力は平面保持を仮定した曲げ解析により算 定した。既往の実験結果は主筋周長比 $\Sigma \phi_{1} / \Sigma \phi_{2} \geqq 1$, コンクリート 強度 $\sigma_{\mathrm{B}} \leqq 60 \mathrm{MPa}$ を満たす試験体 52 体である。これらの実験範囲 は $\Sigma \phi_{1} / \Sigma \phi_{2}=1.0 \sim 2.0, \mathrm{p}_{\mathrm{w}}=0.21 \sim 1.51 \%, \sigma_{\mathrm{B}}=22.6 \sim 58.1 \mathrm{MPa}, \mathrm{b}_{\mathrm{si} 2}=$ $1.61 \sim 4.26$ となっている。図中の記号は実験報告による破壊モード で, B1 が 1 段目主筋の付着割裂破壊，B2 が 2 段目主筋の付着割裂 破壊，S がせん断破壊，FB が曲げ降伏後の付着割裂破壊，F が曲 げ降伏（曲げ降伏以降のせん断破壊を含む）を示す。

図17によれば，計算值は一部の試験体に対して危険側の評価とな るが，多くの試験体について安全側の評価を与えている(なお，F, FB 試験体で $\mathrm{Vexp} / \mathrm{Vmu}<1$ となる試験体は 1 段目主筋の降伏後，2段 目主筋が降伏する以前に付着割裂破壤またはせん断破壊を生じたも

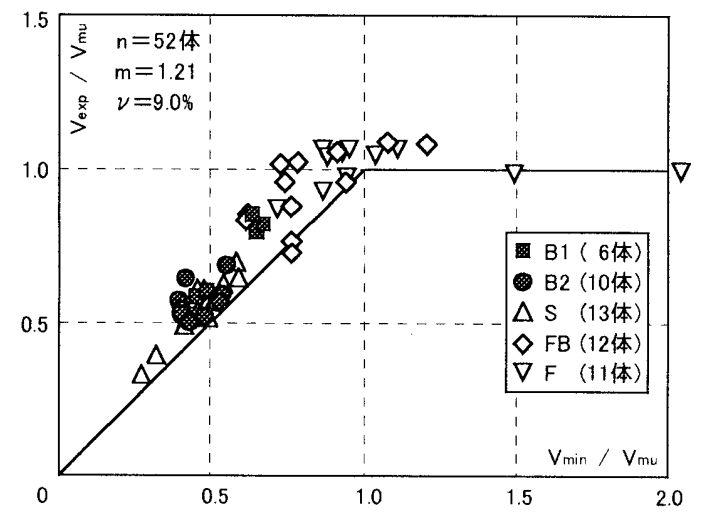

図17 $V_{\exp } / V_{m u}-V_{\min } / V_{m u}$ 関係 
のと思われる)。また, B1，B2，S 試験体に対して, 実験値の計算 值に対する比 $\mathrm{V}_{\exp } / \mathrm{V}_{\min }$ の平均および変動係数はそれぞれ $\mathrm{m}=1.21$, $v=9.0 \%$ あり，その適合性は良好である(因みに式(11)〜 (16)に代 えて勒性保証指針を用いると $\mathrm{m}=1.00, v=12.0 \%$ となり現状よりも幾 分プロット值は危険側にばらつく)。また, 図18は図17に対して破 塤形式の整合性を検証するために, 実験報告による破壊形式に応じ て部材耐力を評価した場合を示したものである。ここで, FB 試験 体と $\mathrm{F}$ 試験体は，横軸の計算值が全て 1.0 となるので除外した。図 18では, S 試験体において過大評価となる傾向がみられるものの, B1 および B2 試験体については図17とほぼ同様の分布を示してお り, 式(10)〜 (17)の良好な適合性を確認することができる。なお, 本検証で用いた B1 試験体(6.体)は全て $\Sigma \phi_{1} / \Sigma \phi_{2}=2.0$ であり，逆に これが 2.0 末満で且つ B1 試験体となるものは認められなかった。

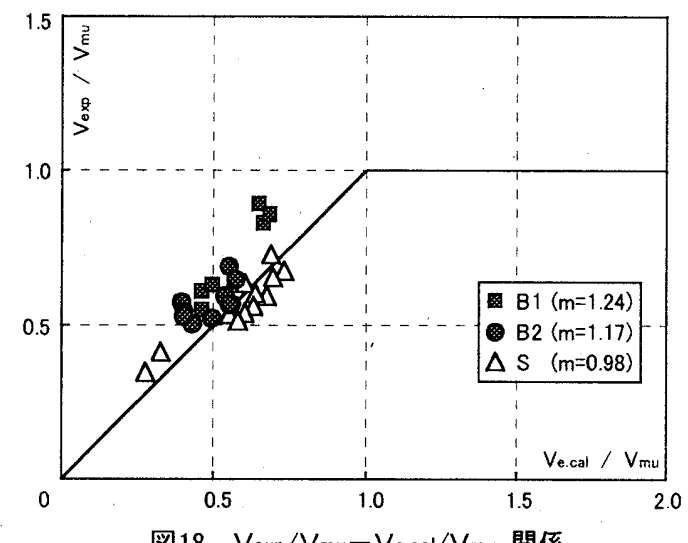

図18 $V_{e x p} / V_{m u}-V_{e . c a l} / V_{m u}$ 関係

\section{5. 結論}

1 段目主筋が 2 段目主筋と同量以上となる 2 段配筋梁の付着割裂実 験を行い, 以下の知見が得られた。

1)全て 2 段目主筋の付着割裂破壞により最大耐力に至ったが，2段目 主筋の付着割裂強度に対して，1 段目主筋本数による明確な差異は 認められなかった。

2) 同一横補强笳比の場合， 2 段目主筋の付着割裂強度は，中子筋の 有無に関わらずほぼ等しかった。しかし，2段目主筋が付着割裂強度 に達したときの，1 段目主筋の付着応力は中子筋を配した方が高く， これにより最大耐力も向上した。

3) 2 段目主筋に直接掛かる横補強筋(本文中では内側補強筋)の，2段 目主筋の付着割裂強度に対する効果は，1段目主筋に直接掛加る外 周補強筋や中子筋のそれと同等であった。

4) 2 段目主筋の付着割裂強度に及ぼす 1 段目主筋の影響に関して, 對 比地らの提案式に修正を加えた。修正式は本実験および既往付着実 験に対して良好な対応を示した。また，設計での利用を考慮して，そ の簡略式を提案した。

5)提案した簡略式を基に既往の 2 段配筋部材のせん断耐力を評価した ところ, 良好な対応関係を示した。

本研究では 2 段配筋部材における 2 段目主筋の付着割裂強度およ び部材としての付着割裂耐力について検討した。曲げ降伏後の勒性能 など, 変形性状については別途, 検討が必要である。誘導した 2 段目主 筋の付着割裂強度式(式(10))については, およそ $\Sigma \phi_{1} / \Sigma \phi_{2}=1.0 \sim 2.0$, $\mathrm{p}_{\mathrm{w}}=0.2 \sim 1.5 \%, \sigma_{\mathrm{B}}=24 \sim 60 \mathrm{MPa}, \mathrm{b}_{\mathrm{si} 2}=1.6 \sim 4$ の範囲で適合性を検
討したが，各影響因子についての系統的な実験が不足しており，更なる 実験データの蓄積が望まれる。また，2段配筋部材における1段目主筋 の付着割裂強度は未だ十分に解明されておらず，今後，検討すべき課 題である。

\section{謝辞}

本研究では, 多くの貴重な実験データを参照させて頂きました。 ここに記して感謝の意を表します。

\section{参考文献}

1)大屋戸理明 ·金久保利之・藤沢正視・園部泰寿：2 段配筋を有する鉄筋 ンクリート梁の付着性状, コンクリート工学年次論文報告集, Vol.15, No.2, pp.187-192, 1993.6

2)對比地健一，川村厚司・高木仁之·狩野芳一：二段配筋の内側主筋位置 における付着割裂破壊，コンクリート工学年次論文報告集，Vol.16， No.2, pp.241-246, 1994.6

3)對比地健一, 川村厚司, 高木仁之, 狩野芳一：二段配筋における内側主 筋位置での付着割裂破壊(その1. 実験概要及び実鈳結果)，日本建築学 会大会学術講演梗概集, C 構造 II, pp.221-222, 1993.9

4) 日本建築学会：鉄筋コンクリート造建物の勒性保証型耐震設計指針・同 解説, 1999.8

5)前田匡樹 - 小谷俊介 ·青山博之 : 鉄筋コンクリート部材の付着割裂強度 式の提案, 日本建築学会構造工学論文集, Vol.38B, pp.293-306，1992.3

6)藤井栄 - 森田司郎 : 異形鉄筋の付着割裂強度に関する研究-第 1 報 付着割 裂破壊を支配する要因についての実験結果-，日本建築学会論文報告集， pp.47-54, 1982.9

7)岩倉知行, 大屋戸理明, 金久保利之, 藤沢正視, 広沢雅也, 園部泰寿 : 2 段配筋を有する鉄筋コンクリート部材の付着割裂強度(その 22 段配筋部 材の付着割裂強度), 日本建築学会大会学術諢演梗概集, C 構造 II, pp.351-352, 1991.9

8)松原洋志，高木仁之，狩野芳一：二段配筋された $\mathrm{RC}$ 部材の付着割裂破壞， コンクリート工学年次論文報告集，Vol.13，No.2，pp.151-156，1991.6

9）田畑卓，西原莌，松本智夫，鈴木英之：束ね鉄筋の付着割裂強度に関す 了研究，日本建築学会構造工学論文集，Vol.43B，pp.211-219，1997.3

10)對比地健一，増田浩之，高木仁之，狩野芳一：二段配筋された梁部材の 付着割裂破壊、コンクリート工学年次論文報告集, Vol.19, No.2. pp.615-620, 1997.6

11) 石川裕次, 木村秀樹，長㟫俊雄，苜野俊介：短スパン梁の強度と勒性に 関する実験的研究，コンクリート工学年次論文報告集，Vol.16，No.2， pp.341-346, 1994.6

12)永井覚, 加藤友康, 別所佐登志：高強度材料を使用した高層 $\mathrm{RC}$ 造短スパ ン梁の実験的研究，コンクリート工学年次論文報告集，Vol.17，No.2， pp.583-588, 1995.6

13)中沢淳, 塚本尚由, 倉本洋, 南宏一: 繰り返し曲げせん断を受ける 13000 キロ級の高強度せん断補強筋を用いた RC 梁のせん断および付着制裂破 壊性状, コンクリート工学年次論文報告集, Vol.12, No.2, pp.221-226, 1990.6

14)増田浩之，小山明男，高木上之，狩野若一：二段配筋梁部材における付 着割裂破壊に関する研究, 日本建筑学会大会学術講演梗概集, C-2 構造 IV, pp.735-736, 1995.8

15)増田浩之, 周力, 對比地健一, 高木仁之, 狩野芳一：二段配筋梁部材の 付着割裂破壊に関する研究，日本建築学会大会学術講演梗概集，C-2 構 造IV, pp.621-622, 1996.9

16）黑川祐介，小山政英，松崎育弘，小曾根茂雄，太田勤，園部泰寿：高強 度材料(コンクリートおよびせん断補强筋)を用いた $\mathrm{RC}$ 梁部材の勒性能 に関する実験的研究(その 1 実験概要及び結果)，日本建築学会大会学術 講演梗概集，C-2 構造IV，pp.901-902，1999.9

(2000年 4 月 10 日原稿受理， 2000 年 9 月11日採用決定) 